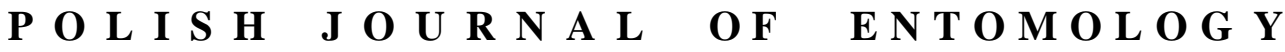

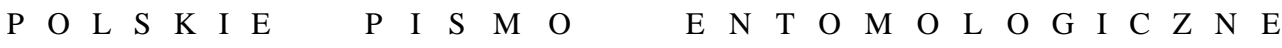

VOL. 87: 57-63

Lublin

31 March 2018

DOI: $10.2478 /$ pjen-2018-0004

\section{New data on the distribution of Parnopes grandior (PALLAS, 1771) \\ (Hymenoptera: Chrysididae) in northern Poland: habitat conditions propitious to this rare cuckoo-wasp species}

\author{
LUCYNA TWERD*, JÓZEF BANASZAK \\ Kazimierz Wielki University, Institute of Environmental Biology, Department of Ecology, \\ Ossolińskich 12, 85-093 Bydgoszcz, Poland
}

\begin{abstract}
Parnopes grandior is a species that until recently was on the brink of extinction in Poland. Current data, however, indicates that it is expanding north-westwards. Most records of this species come from after the year 2000, primarily in northern Poland, especially in the north-eastern part of the country. Simultaneously, our research has shown that anthropogenic habitats like sand quarries and military training grounds are optimal sites for P. grandior.
\end{abstract}

KEY WORDS: Parnopes grandior, Chrysididae, natural habitats, anthropogenic habitats, northern Poland.

\section{INTRODUCTION}

Parnopes grandior (Hymenoptera: Chrysididae), a species that reaches its northern limit of distribution in Poland, is rare and in danger of extinction in this country (threat category CR) (BANASZAK 2004). Despite this threat, however, the species is not protected by Polish law. Being a nest parasite of sand wasps of the genus Bembix FABRICIUS, 1755 (in Poland Bembix rostrata (LINNAEUS, 1758) - threat category VU), it prefers habitats that are suitable for its host, i.e. dry and sunny sites. At the same time, it prefers habitats with a varied structure, with some bare microhabitats (sandy patches) among places more or less covered with herbaceous vegetation, including frequently visited plants of genera like

\footnotetext{
* Corresponding author: 1.twerd@ukw.edu.pl
} 
Thymus L., Armeria WILlD. (BANASZAK 1980), Scabiosa L. (DUCKE 1901) or Euphorbia L. (SCHMIDT 1977). Moreover, as this study has shown, large amounts of dead wood were present in all the habitats where large populations of Parnopes grandior were observed.

Parnopes grandior is rare in Poland and in some other European countries. Of Poland's neighbours, only Belarus can boast a large number of localities (JAROSZEWICZ 2007). Current data (records after 2000) on the distribution of this species in Poland is still far from complete and relates to scattered localities, mostly in northern Poland (JAROSZEWICZ 2007, BANASZAK et al. 2009, TWERD 2010, WENDZONKA 2012, OLSZEWSKI et al. 2013, TWERD 2015, WIŚNIOWSKI 2015). However, the numerous, new localities near the PolishBelorussian border suggest that probably this route of migration is used by the species.

At the same time, analysis of the occurrence of this species indicates that anthropogenic habitats (former arable land, large deforested patches, urban wastelands, gravel/sand quarries) are important as substitute habitats for Parnopes grandior and its host Bembix rostrata, especially when the acreage of suitable natural habitats is decreasing. They can also act as refugia and provide routes of migration for species in the landscape. But it remains unclear whether they can ensure the species' long-term survival.

\section{METHODS}

The fieldwork was carried out in natural and anthropogenic habitats in northern Poland (Figs. 1, 2). All the study sites were at least $1.5 \mathrm{~km}$ apart. Specimens of Parnopes grandior were caught and counted from July until August in 2014-2017. The wasps were collected by searching for them on flowers and in their favourite nesting sites within the study sites. Average sampling times ranged from 2 to $4 \mathrm{~h}$, depending on the areas of the individual study sites. The host species (Bembix rostrata) was present at all the study sites.

\section{RESULTS}

Parnopes grandior was recorded in the following sites:

1. [UTM VU45] "Wrzosowiska Cedyńskie" nature reserve; habitats: dry heath PohlioCallunion; dry inland sandy grassland Koelerion glaucae; xerothermic grassland Festuco-Brometea; extensively managed lowland and highland fresh meadow Arrhenatherion elatioris; area: 72.02 ha; forage plants: Armeria maritime WILLID.

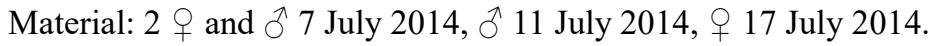

2. [UTM FD62] Dobrowoda; habitat: abandoned sand quarry, area: 4.93 ha; forage plants: Armeria maritima, Thymus serpyllum L. Material: $\widehat{\jmath} 15$ July 2015. 


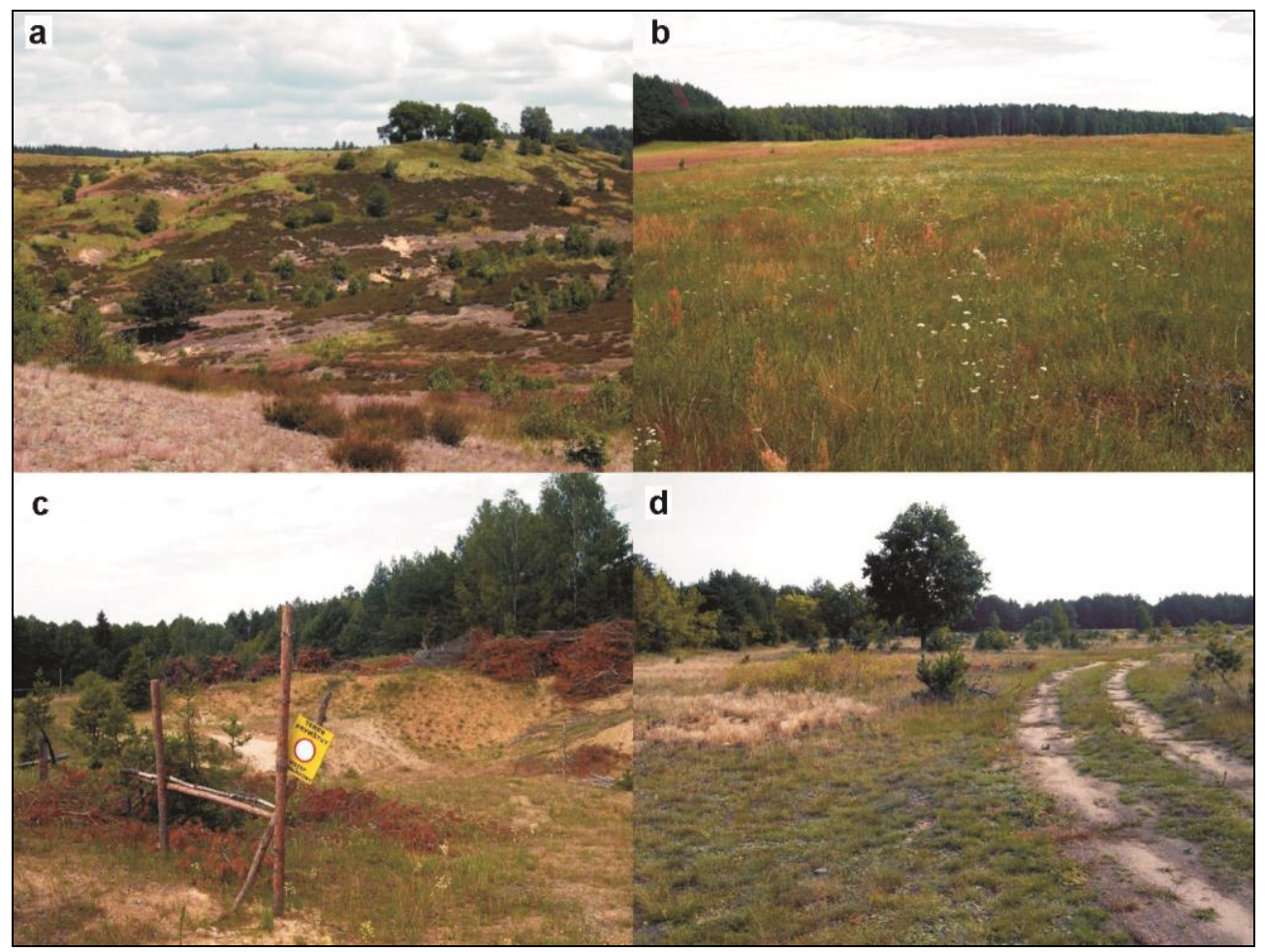

Fig. 1. Selected study sites: a - "Wrzosowiska Cedyńskie" nature reserve; b - Podzałuki; c - Radunin; d - Bydgoszcz-Jachcice.

3. [UTM FE50] Studzianki; habitat: extensively used sand quarry; area: 5.13 ha; forage plants: Armeria maritima, Thymus serpyllum. Material: $\widehat{\partial} 20$ July 2016.

4. [UTM FE60] Kopna Góra; habitat: forest glade; area: 3.98 ha; forage plants: Thymus serpyllum. Material: ô 25 July 2016.

5. [UTM XU99] Bydgoszcz-Jachcice; habitat: a former ( $19^{\text {th }}$-century) military training ground; area: about 50 ha; forage plants: Armeria maritima, Thymus serpyllum. Material: 2 § 3 July 2017.

6. [UTM FD79] Radunin; habitat: extensively used sand quarry; area: 0.69 ha; forage plants: Armeria maritima. Material: 2 and $2 \lesssim 21$ July $2017+5$ observed individuals.

7. [UTM FD79] Podzałuki; habitat: dry hay meadow; area: 4.30 ha; forage plants: Armeria maritima. Material: $\&$ and $\delta 22$ July $2017+4$ observed individuals.

8. [UTM FD89] Górka; habitat: intensively used sand quarry; area: 0.68 ha; forage plants: Armeria maritima, Thymus serpyllum. Material: ㅇ 1 August 2017. 


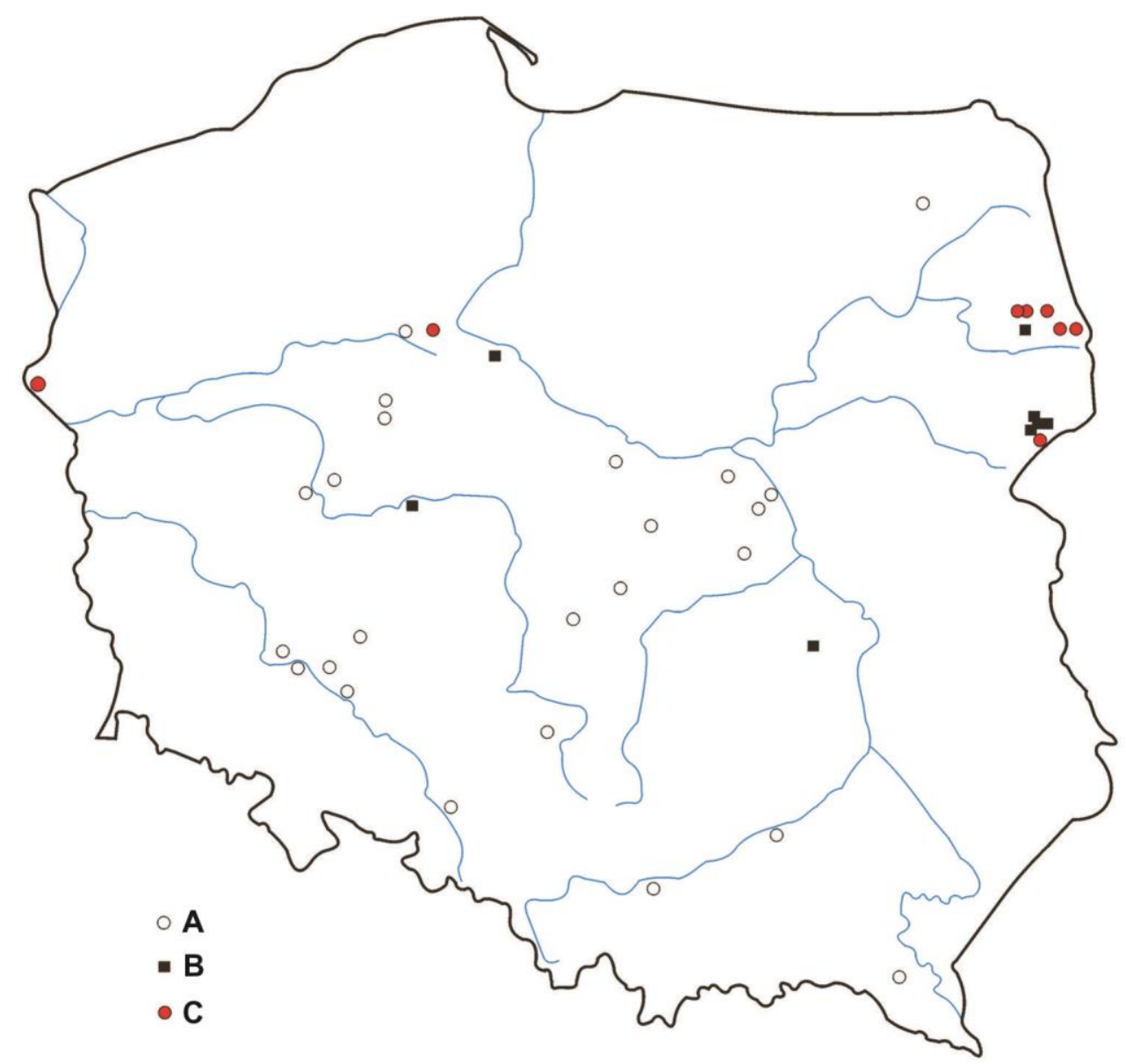

Fig. 2. Distribution of Parnopes grandior in Poland. A - historical localities; B - current localities, i.e. recorded after 2000; C - new localities

Research in the "Wrzosowiska Cedyńskie" nature reserve was conducted by permission of the Regional Director of Environmental Conservation in Szczecin (Decision No. 27/2013; WOPN-ON.6205.15.2015.AR).

\section{DISCUSSION}

In the last four years in Poland Parnopes grandior was recorded in eight new localities in northern Poland. 
At present, landscapes in many European countries are usually dominated by anthropogenic habitats, whereas landscapes with a high proportion of natural or seminatural vegetation are extremely rare. Human impact on the environment causes permanent or temporary transformations of habitats. In many cases the changes lead to a permanent loss of biodiversity, but in others, degradation is only apparent: the changes result in the formation of new habitats that create favourable living conditions for threatened species.

There are many examples of the positive environmental role played by anthropogenic habitats, such as gravel and other quarries, military training grounds, young pine plantations, railway tracks and embankments, which are substitute habitats for many groups of organisms (e.g. Molenda 2013, TROPEK et al. 2010, TwERD 2011, HenEBERG et al. 2013, 2017, MOROŃ et al. 2014).

Our new findings concerning the distribution of Parnopes grandior in northern Poland in the last 4 years also appear to confirm the positive role of anthropogenic habitats in the spread of this species. Only one of the eight new localities was a semi-natural habitat protected as a nature reserve. The other seven are anthropogenic habitats, more or less affected by human disturbance. Published data appear to confirm this relationship (JAROSZEWICZ 2007, BANASZAK et al. 2009, TWERD 2010, WENDZONKA 2012, OLSZEWSKI et al. 2013, TWERD 2015, WIŚNIOWSKI 2015). The available data on the distribution of $P$. grandior after 2000 indicate that about $58 \%$ of the colonized sites are areas transformed by human activity, while the other $42 \%$ are legally protected in various ways. In protected areas, the occurrence of $P$. grandior and its host does not seem to be threatened by changes in land use. In this case, the only threat is ecological succession, which - in conjunction with inadequate protective measures - can limit the occurrence of many species, especially of those associated with open, sunny habitats.

On the basis of our results we conclude that anthropogenic sites colonized by Bembix rostrata and Parnopes grandior may provide effective routes of migration for these species. We are aware that human activity, paradoxically an opportunity but also an obstacle to the occurrence of species, may significantly modify their distribution. An example is the planned real estate development in the vicinity of the gravel quarry at Radunin, where a large population of $P$. grandior was observed (Fig. 1c). In the next few years, this site will probably be levelled and turned into a residential area, which will certainly have a negative effect on the local fauna. In view of this, the presence of potential habitats of this species and its host in the immediate neighbourhood is important. Records of both species in the village of Podzałuki, situated about $1.5 \mathrm{~km}$ from Radunin, indicate that in this case the destruction of the habitat, i.e. conversion of the gravel quarry, will not significantly affect the local abundance population size of $P$. grandior in this area.

The effects of the colonization of anthropogenic habitats within cities can be different. In such a case, a lack of suitable habitats in the immediate neighbourhood of a given site 
can lead to the extinction of local populations. An example of the negative influence of urbanization is the former military training ground in Bydgoszcz, some of which is intended for residential and industrial development (Fig. 1d). Currently, it is a place where all the building waste from construction sites in Bydgoszcz is being dumped. The waste will be used for the construction and repair of roads in the former military training ground. In this case the drastic change in living conditions will undoubtedly have a very negative effect on the population of $P$. grandior, which until the 1950s was frequently recorded in the Bydgoszcz region (SZULCZEWSKI 1917). Nevertheless, the adaptive potential of individual species must be taken into account, as some examples show that even when human impact is very strong (excessive salinity and alkalinity of the soil), stable populations of some parasitic insects (Chrysididae) and their hosts (Sphecidae) can survive (BANASZAK \& Twerd 2010, TWERD et al. 2017).

As a factor transforming the natural environment, human impact is unfavourable from the ecological point of view, as it can lead to irreversible changes in ecosystems. In some cases, however, the resulting new habitats may be of great environmental value and play an important role in the survival and spread of species.

\section{REFERENCES}

BanaszaK J. 1980. Catalogue of Polish fauna XXVI, 3. Cuckoo wasps. Chrysididae. Państwowe Wydawnictwo Naukowe, Warszawa. (in Polish)

BANASZAK J. 2004. Parnopes grandior (Pallas, 1771), Ruby-tailed Wasp. [in:] Z. GŁowaciński, J. NOWACKI (eds.). Polish Red Data Book of Animals. Invertebrates. Instytut Ochrony Przyrody PAN, Akademia Rolnicza im. A. Cieszkowskiego, Kraków - Poznań, 74-75. (in Polish)

BanASZAK J., MiŁKOwSKi M., MikOŁAJCZAK K. 2009. New localities of two very rare hymenopterans in Poland: Parnopes grandior (PALlAS, 1771) and Xylocopa valga GERSTAECKER, 1872 (Aculeata: Chrysididae and Apidae). Polish Journal of Entomology 78(1): 111-113.

BANASZAK J., Twerd L. 2010. High number of cuckoo wasps (Hymenoptera: Chrysididae) in areas directly affected by lime and sodium industry. Polish Journal of Entomology 79(3): 291-305.

DuCKE A. 1901. Beitrag zur Kenntnis der geographischen Verbreitung der Chrysididen und Beschreibung von drei Arten. Zeitschrift für Systematische Hymenopterologie und Dipterologie 1: $353-361$.

Heneberg P., Bogusch P., Řenounek J. 2013. Sandpits provide critical refuge for bees and wasps (Hymenoptera: Apocrita). Journal of Insect Conservation 17(3): 473-490.

Heneberg P., Bogusch P., ŘezÁč M. 2017. Roadside verges can support spontaneous establishment of steppe-like habitats hosting diverse assemblages of bees and wasps (Hymenoptera: Aculeata) in an intensively cultivated central European landscape. Biodiversity and Conservation 26(4): $843-864$. 
Jaroszewicz B. 2007. Parnopes grandior (PALlas, 1771) (Hymenoptera: Chrysididae) in Poland and its status in adjacent countries. Fragmenta Faunistica 50(1): 19-25.

Molenda T. 2013. The protection of anthropogenic habitats in Poland. Journal of Ecology and Health 17(2): 76-80. (in Polish)

Moroń D., Skórka P., Rożej-Pabijan E., Wantuch M., Kajzer-Bonk J., Celary W., MielCZAREK Ł.E., TRYJANOWSKI P. 2014. Railway embankments as new habitat for pollinators in an agricultural landscape. PLoS ONE 9(7): e101297.

Olszewski P., Wiśniowski B., Pawlikowski T., SzPila L. 2013. New data about some rare species of aculeates (Hymenoptera: Aculeata) from Poland. Wiadomości Entomologiczne 32(2): 127-138. (in Polish)

SChmiDT J. 1977. Die Chrysididen der Türkei, insbesondere Anatoliens. Linzer Biologische Beiträge 9(1): 91-129.

SzUlCZEWSKI J.W. 1917. Beitrag zur Chrysididenfauna der Provinz Posen. Zeitschrift der Naturwissenschaftlichen Abteilung der Deutschen Gesellschaft für Kunst und Wissenschaft in Posen 24(1): 29-35.

Tropek R., Kadlec T., Karešová P., Spitzer L., KočÁrek P., Malenovský I., Baňař P., TuF I.H., HEJDA M., KONVIČKA M. 2010. Spontaneous succession in limestone quarries as an effective restoration tool for endangered arthropods and plants. Journal of Applied Ecology 47(1): $139-147$.

Twerd L. 2010. New localities of Parnopes grandior (Hymenoptera: Chrysididae) in Poland. Chrońmy Przyrodę Ojczystą 66(4): 316-318. (in Polish)

TwERD L. 2011. The industrial areas - as a place rich fauna aculeata. Inżynieria Ekologiczna 27: 219228. (in Polish)

Twerd L. 2015. New localities of endangered species Aculeata (Hymenoptera) in "Jelonka" reserve in north-eastern Poland. Parki Narodowe i Rezerwaty Przyrody 34(4): 87-91. (in Polish)

Twerd L., KrzyżyŃski M., Waldon-Rudzionek B., Olszewski P. 2017. Can soda ash dumping grounds provide replacement habitats for digger wasps (Hymenoptera, Apoidea, Spheciformes)? PLoS ONE 12(4): e0175664.

Wendzonka J. 2012. Parnopes grandior and other Aculeata in Warta Landscape Park. Biuletyn Parków Krajobrazowych Wielkopolski 18(20): 105-112. (in Polish)

WiŚNIOwSKi B. 2015. Cuckoo-wasps of Poland. Ojców National Park, Ojców.

Received: 22 September 2017

Accepted: 13 November 2017 